\title{
Female Judges in Saudi Arabia, Hope Versus Reality
}

\author{
Samah al-Agha \\ Assistant Professor, Law Department, Dar al-Hekma University, \\ Jeddah, Kingdom of Saudi Arabia \\ sagha@dah.edu.sa
}

\begin{abstract}
The purpose of this research is to identify and explore the factors that have contributed to the prevention of women from working in the Saudi Arabian judiciary from the viewpoints of male Saudi judges. The study applies the qualitative research method and uses interviews to obtain the required data. It uses primary and secondary resources to support the arguments. The data analysis reveals three main themes under which these factors fall: the legal constraints, the religious constraints, and the cultural constraints. Finally, the study concludes with some findings and recommendations with regard to employing women in the judiciary.
\end{abstract}

\section{Keywords}

female judge - constraints, legal - constraints - religious - constraints, cultural - Sharīah

\section{Introduction}

Despite progress in various fields on women's rights, including their access to all areas of education in Saudi Arabia, it was not until 2006 that women were admitted to law schools. ${ }^{1}$ According to the World Bank's Report, Women

1 A. Profanter, S.R. Cate, E. Maestri and V. Fiorani Piacentini, Saudi Arabia and Women In Higher Education and Cultural Dialogue: New Perspective, available online at https://books. google.com.sa $/$ books?id=8IiTAwAAQBAJ\&pg=PA38\&lpg=PA38\&dq=when+does+THE+FIRS $\mathrm{T}+\mathrm{TIME}+$ females+got + accepted $+\mathrm{in}+$ the + law + schools $+\mathrm{in}+\mathrm{KSA} \&$ source $=$ bl\&ots $=\mathrm{gvNDb} 2 \mathrm{~W}$ icT\&sig=ACfU $3 \mathrm{U}_{1} \mathrm{XTqhPjB} 4 \mathrm{CEm} 88 \mathrm{I}_{4}$ ISGBLrDscoJw\&hl=en\&sa=X\&ved=2ahUKEwjJrraBh8 DqAhWK_qQKHfBnDvIQ6AEwAHoECAoQAQ\#v=onepage\&q=when\%2odoes\%2oTHE\%2O FIRST\%2OTIME\%2ofemales\%2ogot\%2oaccepted\%2oin\%2othe\%2olaw\%2oschools\%2O in\%2oKSA\&f=false (accessed 1 April 202O). 
Business and the Law (WBL), since 2017 the Kingdom of Saudi Arabia has progressed rapidly towards gender equality, ranking it the top reformer and improver among Gulf Cooperation Countries (GCC) and second in the Arab world. ${ }^{2}$ Peculiarly, however, this progress has not resulted in gender diversification of the judiciary.

Women who graduated from law schools started to practice law and build careers in legal firms and have been appointed in senior governmental roles such as prosecutors. However, to date, as of writing this article, no woman has been appointed as a judge, and the reasons remain unknown. Hence the importance of this research. Until now, no identified research has explored the reasons behind the non-appointment of women in the Saudi Arabian judiciary unlike in other Arabic and Islamic countries where the issue has been studied.

The purpose of this research is to identify and explore the factors and the potential barriers that have contributed to the prevention of women from working in the Saudi Arabian judiciary. One way to achieve this aim is by studying the views of male Saudi judges and by examining their perspectives on the issue. In doing so, this article will refer to research and a number of studies on women's employment in the judiciary in Arab and Islamic countries as well as refer to literature on the evolution of women's movement in the legal sphere in Saudi Arabia.

\section{Regional Survey}

In Saudi Arabia, women are still struggling for their rights in certain fields such as the judiciary, although Saudi Arabia affirmed its commitments to achieve gender justice on 7 September 200o, by signing and ratifying the Convention on the Elimination of All Forms of Discrimination against Women and although Article 7 of the same convention requires States to 'take all appropriate measures to eliminate discrimination against women in the political and public life of the country.' 3

In 2016, Al-Farran reported that Saudi Arabia had made changes to eliminate discrimination against women where a number of decrees and orders

2 World Bank Group, Women, Business and the Law 2020 Report, available online at https:// openknowledge.worldbank.org/bitstream/handle/10986/32639/9781464815324.pdf (accessed 1 April 2020).

3 UN Human Rights, Office of the High Commissioner, Women in the Judiciary in the Arab States Removing Barriers, Increasing Numbers, available online at https://www.unescwa.org/ publications/women-judiciary-arab-states (accessed 20 April 2020). 
were issued to recognize women's rights. ${ }^{4}$ Women joined the workforce in legislative and executive authorities. For example, in 2005, Nora al-Fayez was appointed Deputy Secretary of Education which, for the first time, placed a woman in a high position of responsibility within the Saudi Government. ${ }^{5}$ In 2013, a royal decree allowed Saudi women to become members in the Consultation (Shüra) Council, where currently 30 of the 150 members seated are women. ${ }^{6}$ In 2018, women were also allowed to administer the law by working in public prosecution. ${ }^{7}$ On 24 February 2019, and for the first time in the field of diplomacy, a woman, Saudi Princess Nora bint Bandar, was appointed as ambassador to the United States. ${ }^{8}$

Female students were first admitted to law school in 2006 and by 2010 more than 1,500 women had graduated. However, women were not allowed to practice law in courts as lawyers until 2013 when the Ministry of Justice registered the first female lawyer as a legal trainee; since then the number of female lawyers has increased. ${ }^{9}$

Nevertheless, women's participation in the judiciary workforce in Saudi Arabia is still uniquely restricted, and no woman has yet been appointed as judge unlike women in many Arab and Islamic countries which have preceded Saudi Arabia in this regard. For example, Iraq was the first Arab country to appoint Zakiah Hakki as the first female judge in $1959 .{ }^{10}$ Following this advancement, several Arab countries such as Morocco in 1961, Tunisia and Lebanon in 1966, Yemen in 1971, Syria in 1975, and Sudan in 1976 appointed women as judges. ${ }^{11}$ This progress stopped in the late 1970s and during the 1980s, with the only breakthrough being the State of Palestine which appointed its first female judge in 1982. One reason for this standstill could be attributed to the emergence of

A. al-Farran, Increasing Women's Labour Market Participation in Saudi Arabia: The Role of Government Employment Policy and Multinational Corporation, PhD Dissertation, College of Business, Victoria University, Melbourne, vic, 2016. Profanter et al., supra note 1.

6 Human Rights Commission, Kingdom of Saudi Arabia, How is equality between men and women achieved under the Kingdom's laws?, available online at https://www.hrc.gov.sa/ en-us/HumanRightsInSaudi/Pages/equalityrights.aspx (accessed 2 April 2020).

7 Saudi Gazette, 'Prosecution Hiring Women Investigators', available online at https://sau digazette.com.sa/article/528078 (accessed 21 April 2020).

8 Saudi Gazette, 'Saudi Deputy King issues 3 Royal Orders: Reema bint Bandar appointed as Saudi Ambassador to the USA, available online at https://www.saudigazette.com.sa/ article/559820 (accessed 2 June 2020).

9 International Commission of Jurists, 'Women and the judiciary', Geneva Forum Series No.1 (Geneva: ICJ, 2013), available online at https://www.icj.org/geneva-forum-series-no-1 -women-and-the-judiciary/ (accessed 2 June 2020).

10 UN Human Rights, supra note 3.

11 Ibid. 
political and religious conservatism, which caused a backlash against women's participation in public positions in some Arab countries. ${ }^{12}$ The evolution to appoint women to the judiciary resumed in Libya in 1991, Jordan in 1996, Egypt in 2003, Bahrain in 2006, the United Arab Emirates (UAE) in 2008, Qatar in 2010, and Mauritania in 2013. ${ }^{13}$ In 2016, the Saudi authorities approved the appointment of Shaima Aljubran by the Court of Appeal in Dammam as the first woman arbitrator in a dispute in a commercial court, which is considered a quasi-judicial body. ${ }^{14}$

Although the participation of Saudi women has been evidenced with the appointment of women as members of the Shüra Council, lawyers, ambassadors, arbitrators and recently as prosecutors, there is still a backlash against their serving as judges. Consequently, there have been calls by members of the Shüra Council to appoint women to the judiciary. In 2018, members Faysal al-Fadhel, Lateefa al-Shaalan and Atta al-Subaiti, who served on the Council's Islamic Affairs and Judicial Committee, presented a recommendation to the to the Shüra Council that women be appointed to the judiciary. ${ }^{15}$ The recommendation referred to the availability of qualified female law graduates, to the existence of vacant judicial posts and to calls for competent Saudi women who were legally and religiously qualified to hold the position of judge. ${ }^{16}$ Their main motive was that appointing women to the judiciary was compatible with the Kingdom's 'Vision 2030' that called for 'empowering women and investing in their potential and aptitudes.'17 The Shüra Council rejected the recommendation. ${ }^{18}$ On 9 June 2020 , a second recommendation was presented to the Shüra Council calling for the appointment of women as judges. Notably, the second recommendation suggested that women could be appointed as judges in the Personal Status Courts only but not in other courts in an attempt to convince the Shüra Council members and to lessen their decision-making burden. For the second time the Shüra Council rejected the recommendation without offering any justification for their reasoning. ${ }^{19}$ Latifa al-Shaalan,

\footnotetext{
12 Ibid.

13 Ibid.

14 Ibid.

15 H. Toumi, Saudi Arabia could soon appoint women as judges, available online at https:// gulfnews.com/world/gulf/saudi/saudi-arabia-could-soon-appoint-women-as-judges-1.22 $6225^{2}$ (accessed 10 June 2020).

16 UN Human Rights, supra note 3.

17 Toumi, supra note 15.

18 Ibid.

19 Middle East News, 'Saudi Shüra Council refuses to appoint female judges', available online at https://www.middleeastmonitor.com/2020o619-saudi-shura-council-refuses-to-appoint -female-judges/ (accessed 10 June 2020).
} 
a member of the Shüra Council, stated, 'the Council had blocked the second attempt to study a recommendation to appoint women as judges although the Kingdom's justice system "does not" prohibit the appointment of women as judges'.20

In the Arab world, some studies were purposely conducted to establish support for appointing women in the judiciary while other studies aimed to oppose such appointment. In Egypt, for instance, Amira Bahay el-Din shed light on the hindrances that female law graduates faced when seeking employment in legal professions such as the judiciary, which was dominated by men. ${ }^{21}$ She found that the Egyptian Constitution and laws stipulate gender equality in all public-sector employment. She reported that various scholars interpreted the Qurān and Sunnah differently. She criticized the media and the public opinion for propagating the notion that female law graduates should work only as lawyers. ${ }^{22}$ Engy Abdelkader conducted a comparative study to examine the situation of women's appointment in the judiciary in three Islamic countries that are geographically and culturally different: Indonesia, Iran and Egypt. ${ }^{23}$ She discovered that the tolerant and inclusive interpretation of Islamic jurisprudence in Indonesia facilitated women's entry into the country's judiciary, ${ }^{24}$ explaining that 'of the three countries, Indonesia enjoys the highest rates of female judgeships and an absence of gendered interpretative restrictions $v i s-a ̀-v i s$ the law or normative social practice. ${ }^{25}$ Engy Abdelkader pointed out that, in Egypt, the restrictive interpretation of Islamic jurisprudence had excluded women from the judiciary for decades before allowing them to work in the judiciary; currently the percentage of women serving as judges lags far behind that in Indonesia. ${ }^{26}$ In Iran, the Shicite dominance in Iranian society has played a role in women's entry into the judiciary because, according to classical Shicite jurisprudence, women are not allowed to work as judges. This however-according to the Shi'ites—can change in response to changing times

\footnotetext{
$20 \quad$ Ibid.

21 A. Bahay el-Din, 'Female employment on the judiciary: Legislative authorization and practical barriers', in Abdel Moneim Muslim (ed.), Women Judges in the Arab Region: Point, Counterpoint (Cairo: The Arab Center for Independence of the Judiciary and the Legal Profession 'ACIJLP', 2001), p. 8.

22 Ibid.

23 E. Abdelkader, 'To judge or not to judge: A comparative analysis of Islamic jurisprudential approaches to female judges in the Muslim world (Indonesia, Egypt and Iran)', Fordham International Law Journal 37(2) (2014): 309-372.

24 Ibid.

25 Ibid., p. 367.

$26 \quad$ Ibid., p. 369 .
} 
and circumstances, but currently the restrictive interpretations of Islamic law's textual sources are still adopted. ${ }^{27}$

On the other hand, in response to demands for women's enrolment in the Egyptian judiciary, a number of studies were conducted with the purpose of opposing women's employment therein. For example, Abd al-Hamid Mayhoub was critical to the idea of appointing women as judges, claiming that, 'Islamic jurists have stipulated that judges must be men'28 and supporting his claim with evidence from Islamic jurisprudence including the Qurān and Sunnah. ${ }^{29}$ He affirmed that women could not be judges because they are too weak and too emotional to arrive at a decision of refusal of defence. He also claimed that a women's presence in court did not conform to Islamic values concerning the protection of women and the preservation of their dignity because all types of men with differing morals would be encountered in a court. ${ }^{30}$

In the Gulf area, according to a publication by the Bahraini Supreme Council for Women, Bahrain was the first Gulf State to appoint a female judge in 2006, with the number of female judges eventually reaching twenty-one. ${ }^{31}$ This increase reflects the positive effects of education, laws and regulations issued in Bahrain, and the realization of the principle of equal opportunities between men and women in rights and duties while pursuing public service. ${ }^{32}$

On 1 July 2020, eight women in Kuwait were promoted as judges for the first time after they had been involved in the investigation and prosecution of different cases for more than 5 years. ${ }^{33}$ In Saudi Arabia, the issue of women's appointment in the judiciary was not of great importance. In 2013, the Special Rapporteur on the Independence of the Judiciary concluded that Saudi Arabia does not allow women to work as judges and that men and women were unequal physically, emotionally, and intellectually. ${ }^{34}$ Also, the International

$27 \quad$ Ibid., pp. 36o-361.

28 A. al-Hamid Mayhoub, 'Scope in Islamic law for women judges: The condition of being male', in A. Moneim Muslim (ed.), Women Judges in the Arab Region, Point, Counterpoint (Cairo: The Arab Center for Independence of the Judiciary and the Legal Profession 'ACIJLP', 2001), p. 43.

29 Ibid.

$30 \quad$ Ibid.

31 Supreme Council for Women, Bahraini Women in Numbers, available online at https:// www.scw.bh/en/MediaCenter/Documents/Final-Numbers-May-2016.pdf (accessed 10 June 2020).

$32 \quad$ Ibid.

33 Gulf News, 'Kuwait boosts women's empowerment in judicial system', available online at https://gulfnews.com/world/gulf/kuwait/kuwait-boosts-womens-empowerment-in-judi cial-system-1.72348197 (accessed 10 June 2020).

Abdelkader, supra note 23 at 310. 
Commission of Jurists (ICJ) reported in the Geneva Forum in 2014 that, 'there are no women in the Saudi Arabian Judiciary because women are prohibited from working as judges.' ${ }^{35}$ The Saudi scholar, Abdulrahman Yahya Baamir, summarizes the whole situation by claiming that allowing women to work as judges or arbitrators is contradictory to Sharīah and that this matter is not debatable. ${ }^{36}$

Rejection of the Shüra Council's - as well as other scholars—recommendation to appoint Saudi women as judges has implications for women lawyers and their future aspirations to work in the judiciary. Since no research has been conducted to identify the reasons why women have not been able to join the judiciary in Saudi Arabia, this research comes as a step towards understanding the reasons why, despite the progress women have made in Saudi Arabia in all fields, there is still resistance to accepting them as judges. It is important to understand the varying perspectives of different parties involved in the decision-making process. One of these perspectives is that of male judges who have dominated the profession. No research was conducted to discover if they held the traditional values and gender stereotypes, within the context of the local patriarchal social and cultural values that are reinforced by the Wahhabi school of thought, which has dominated the Kingdom since its establishment, and if they would accept women as partners in the profession.

As a result, this research aims to fill a gap in our understanding why women are restricted from working as judges in Saudi Arabia by examining in depth the reasons why women are not being appointed in the judiciary from the perspective of male Saudi judges, thereby highlighting and analysing the factors and barriers they identify as constraints to female judgeships.

\section{3} Methodology

This research uses information from primary and secondary resources. Primary data were collected using semi-structured interviews with Saudi judges of different ranks from various cities throughout Saudi Arabia, as supported by referring to judicial cases. Data were also collected from laws, decrees, the Holy Qur'ān, Sunnah and fatwās (legal opinions of Islamic scholars).

35 International Commission of Jurists, supra note 9.

36 A. Yahya Baamir, Sharíah Law in Commercial and Banking Arbitration: Law and Practice in Saudi Arabia (London: Routledge, 2016). 
This study applies qualitative research methods because the research focuses on human thoughts, beliefs and experiences. ${ }^{37}$ Therefore, we have conducted semi-structured interviews where a set of questions were prepared, but a window provided for clarification and elaboration when needed. One of the questions included in the interview guide was 'Can women work as judges in Saudi Arabia? Explain'. Another question was 'Describe how religion, law and culture in Saudi Arabia may or may not play a role in appointing women as judges in the country'.

Due to the difficulties resulting from gender segregation in conducting face-to-face interviews with some judges, we opted to interview them by telephone or through WhatsApp. Although a total of 15 judges were contacted, only 10 accepted our request for an interview. We recruited the judges through 'snowball' sampling; e.g., one judge managed to put the researcher in touch with other judges who also referred some of their colleagues. The judges were assured that their identities would remain anonymous and that they could withdraw from the study any time they felt uncomfortable. If gaps in their answers were discovered while analyzing the data, the researcher requested more clarification from some participants when needed. Further comprehensive and probing questions were posed to clarify all points in their answers which added to the richness of the data. Some of their answers were similar, so it was easy to assume that this led to data saturation despite the fact that few of those interviewees had evaded making a direct response to questions they thought of as sensitive.

Several obstacles arose during the data collection period, e.g., obtaining access to the participant judges was very challenging. Acquiring their permission to conduct such an interview was even more difficult due to their busy court schedules and the sensitive nature of their positions. In addition, it was not easy for a female researcher to meet with them in person, which meant that studying their body language remained an unknown factor. Long waits to interview judges personally in their offices was one obstacle, which meant that sometimes it was impossible to interview them at all. At times, it was frustrating to wait for months to communicate with them. Because the interviews with the judges were all conducted in the Arabic language, this meant that they had to be translated into English. A colleague who is fluent in both English and Arabic verified the translation of the interviews.

37 J.W. Creswell, Qualitative Inquiry and Research Design: Choosing Among Five Approaches (London: Sage, 2013), p. 9. 


\section{$4 \quad$ Analysis and Discussion}

Data collected from the interviews was applied in analyzing and discussing the issue in question, and thereafter the findings were based on a theoretical position regarding the question of barriers for women's appointment in the judiciary. This research first outlines, then interprets and discusses, categories and themes. To ensure its reliability, the analysis was also done by a fellow researcher who had experience in qualitative research. Any discrepancies in both of our analyses were discussed until they were resolved and a consensus was reached. Based on the analysis, three main themes were identified: the legal constraints, the religious constraints, and the cultural constraints. Each theme is further divided into several some sub-themes to discuss.

\subsection{The Legal Constraints}

In response to questions regarding the presence of legal constraints, all the judges reported that there was nothing in the current Saudi legal system that expressly required a judge to be a male. For example, one judge said:

The Basic Law of Governance, which is our Constitution, emphasizes equality in all public sectors and prohibits discrimination against citizens based on gender. Therefore, all laws are compatible with the Constitution because the Constitution is superior to laws.

Another judge welcomed women's appointment in the judiciary by saying:

Several women have been appointed as female officers in our court and they do their job professionally and faithfully. I think they will be the same if they work as judges. I hope they will have the chance soon to work in the judiciary because there is nothing in laws that prevent them from doing so and I will personally support them.

The judges' confirmation that there is nothing in the Saudi law that stops women from becoming judges finds support in the fact that there is no gender stipulation in the related legal systems in Saudi Arabia. This is evident in laws such as the Basic Law of Governance that was issued by a Royal Decree in 1992, the Law of the Judiciary that was enacted in 1975 and modified in 2007 , and the modified Arbitration Law 2012.

Article 28 of the Basic Law of Governance states that, "The State shall facilitate job opportunities for every able person, and enact laws to protect the worker and the employer'. Article $5^{2}$ of the Basic Law of Governance states 
that, 'Judges shall be appointed and relieved by Royal Decree, based on a proposal of the Supreme Judiciary Council, in accordance with provisions of the Law'. Also, Article 8 of the Basic Law of Governance provides that 'Governance in the Kingdom of Saudi Arabia is based on justice, consultation (Shüra) and equality according to Islamic Sharíah. Article 10 of the same Law states that 'the State shall aspire to promote family bonds and Arab-Islamic values. It shall take care of all individuals and provide the right conditions for the growth of their talents and skills'. These articles clearly show that the Saudi law grants women the same job opportunities that it grants men.

Interestingly, Article 37 of the Saudi Law of the Judiciary lists a number of stipulations for the person who assumes the position of judge; ${ }^{38}$ however, it does not specify gender in the requirements codified for the appointment of judges. Article 17 of the Statute of Administrative Judiciary (dīwān al-mazālim) 2007 states that appointment of judges is conducted in accordance with the requirements codified in the Law of Judiciary for appointment of judges. ${ }^{39}$ This again does not limit the appointment of judges to men.

Both, the Saudi Basic Law of Governance and the Law of the Judiciary do not prohibit women from working in the judiciary. The Basic Law of Governance affords every Saudi citizen the right to hold public positions without discrimination based on gender, language, or religion. Moreover, the Law of the Judiciary places no restriction on women's employment in the judiciary.

Similarly, the new Saudi Arbitration Law 2012 does not contain an article that stipulates a certain gender for appointment as arbitrator. Article 14 of the law that clarifies the conditions of appointment does not stipulate a specific gender, ${ }^{40}$ it applies to both men and women with no discrimination. The

38 Article 37: To be appointed as a judge, a candidate shall fulfill the following requirements: (1) shall have the Saudi nationality; (2) shall be of good character and conduct; (3) shall be fully qualified to hold the position of judge in accordance with Shari`ah provisions; (4) shall hold a degree from one of the Sharīah colleges in the Kingdom of Saudi Arabia or any equivalent certificate provided that, in the latter case, he shall pass a special examination to be prepared by the Ministry of Justice. In case of necessity, persons well-known for their learning and knowledge who do not hold the required degree may be appointed as judges; (5) shall not be less than 40 years of age if appointed to the rank of an appellate judge, and not less than 22 if appointed to any other rank in the judiciary; (6) shall not have been sentenced to a hadd (Qurānic prescribed punishment) or a ta'zīr (discretionary punishment) or for a crime affecting honor, or punished by disciplinary action dismissing them from a public office, even though they may have been rehabilitated; The Saudi Law of Judiciary 1975 .

39 The embassy of the Kingdom of Saudi Arabia, The Law of The Judiciary, available online at https://www.saudiembassy.net/law-judiciary (accessed 12 June 2020).

40 Article 14 requires that 'an arbitrator must: (1) be legally competent, (2) be of good conduct and behavior, and (3) hold at least a college degree in Islamic legislation knowledge or regular knowledge .... 
following case explains how Shaima al-Jubran was appointed as the first Saudi female arbitrator. ${ }^{41}$

\subsubsection{Shaima al-Jubran's Case}

In 2016, in order to solve a commercial dispute by arbitration in the Eastern Province of Saudi Arabia, each party of the disputation appointed an arbitrator; the claimant (Mr. X) appointed a male arbitrator and the respondent (Mr. Y) appointed a female lawyer, Shaima al-Jubran, as an arbitrator ${ }^{42}$ on his side. Since both arbitrators could not agree on a third arbitrator (weighted arbitrator), they filed a lawsuit before the Administrative Court of Appeal in Dammam, which was the designated court for such a case, requesting the court to appoint the third arbitrator. ${ }^{43}$ The Court wrote to several people asking them to function as third weighted arbitrator in the arbitral tribunal, but several refused because they were afraid that the arbitral award would be void since one of the two arbitrators was a woman. Finally, both arbitrators agreed on the court's choice for a third arbitrator, and the court approved the arbitral tribunal. ${ }^{44}$ Notably, according to Article $15(4)$, this court's decision about the appointment of an arbitrator, in accordance with Article 15(1),(2) is final and not subject to appeal..$^{45}$ Interpretably and practically, the Administrative Court

41 M. Hamad Almulhim, The First Female Arbitrator in Saudi Arabia, available online at http:// arbitrationblog.kluwerarbitration.com/2016/o8/29/the-first-female-arbitrator-in-saudi -arabia/?doing_wp_cron=1592069o97.187386o359191894531250 (accessed 12 June 2020).

42 N. Ghonaim, Women working in Arbitration: Between Permissibility and Prevention, available online at https://www.arbitrationkw.com/\%D8\%A8\%D8\%AD\%D8\%AB-\%D9\%85 \%D8\%B3\%D8\%A3\%D9\%84\%D8\%A9-\%D8\%B9\%D9\%85\%D9\%84-\%D8\%A7\%D9\%8 4\%D9\%85\%D8\%B1\%D8\%A3\%D8\%A9-\%D9\%83\%D9\%85\%D8\%AD\%D9\%83\%D9\%8 $5 \% \mathrm{D} 8 \% \mathrm{Ag} /$ (accessed 12 June 2020).

43 Article $15 / \mathrm{B}(2)$ of the Saudi Arbitration Law states that: 'the arbitral tribunal consists of three arbitrators, each party shall choose an arbitrator for him, and then the two arbitrators agree to choose the third arbitrator. If one of the parties does not appoint an arbitrator within fifteen days following the reception of an application concerning that from the other party, or if the two appointed arbitrators do not agree on choosing the third arbitrator within fifteen days following the date of the appointment of the most recent of them, the competent court undertakes choosing him at the request of this who is concerned about acceleration, and this is to be done within fifteen days from the date of submitting the application. And the arbitrator chosen by the appointed arbitrators or chosen by the competent court shall be the president of the arbitral tribunal. And these provisions shall apply in the case of the formation of the arbitral tribunal of more than three arbitrators': The New Saudi Arbitration Law 2012.

44 Ghonaim, supra note 42.

45 Article 15(4): Without prejudice to the provisions of the 49th and 5oth Articles of this law, the decision of the competent court concerning the appointment of the arbitrator in accordance with the paragraphs ( 1 and 2 ) of this Article is not subject to appealing independently by any way of appeal: Saudi Arbitration Law 2012. 
of Appeal in Dammam did implicitly accept the appointment of a female arbitrator in this case since it did not dismiss her appointment. Indeed, this case constitutes a landmark decision in the history of Saudi legal systems in general and in Saudi arbitration in particular, and this invokes in one's mind the question of whether future cases will take a similar approach or if the decision in question will be the first and last one.

\subsubsection{Saudi Women as Prosecutors}

On 26 August 2018, fifty Saudi women were appointed to the 'Public Prosecution' ${ }^{46}$ When comparing the conditions of appointment that are stated in Article 37 of the Law of the Judiciary to the conditions stated in Article 14 of the Saudi Arbitration Law 2012 and the conditions stated in Article 1 of the Law of Public Prosecution ${ }^{47}$ (previously Bureau of Investigation and Prosecution), one finds that there is no gender stipulation in the three laws. This corresponds with what the Shüra Council member, Latifa al-Shaalan, stated in defence of her proposal to appoint women as judges.

Although women are allowed to work in arbitration and public prosecution circuit, they are still uniquely restricted from entering the judiciary. With this in mind, the chance for women to work in the judiciary is on the increase if we acknowledge that judges and prosecutors have the same status according to the Law of Public Prosecution. ${ }^{48}$ Both the judiciary and public prosecution share public responsibility and are mutually complementary in their assertion on neutrality and impartiality and in strengthening the rule of law. ${ }^{49}$ Moreover, allowing women to work in prosecution is an admittance of the fact that they are accountable, competent and trustworthy because prosecutors act on

46 Saudi Gazette, 'Saudi women become Public Prosecution investigators for the first time', available online at https://saudigazette.com.sa/article/575574, accessed 12 June 2020.

47 Article 1 of the Law of Public Prosecution (previously, the Bureau of Investigation and Prosecution) states: 'To be appointed a member of the Bureau, one shall satisfy the following: (a) be a Saudi national; (b) be of good character and conduct; (c) be legally competent; (d) be a holder of a degree from one of the Sharī'ah colleges in the Kingdom or any other equivalent degree or a holder of a law degree from one of the Kingdom's universities or any other equivalent degree. In the case of being a holder of an equivalent degree, he shall pass an examination especially held for that purpose; (e) be not less than 22 years old; ( $\mathrm{f}$ ) be physically fit for service; $\mathrm{g}$ ) not have been sentenced to hadd (Qur'ānic prescribed punishment) or $t a z i \bar{r}$ ('discretionary punishment') or a crime impinging on integrity, or punished by disciplinary decision dismissing him from public office, even if rehabilitated; (h) shall successfully pass the examination especially held for the purpose of appointment'.

48 Royal Decree No. 240/A on 17 June 2017, available online at https://www.spa.gov.sa/ viewstory.php?lang=ar\&newsid=1640804 (accessed 12 June 2020).

Ibid. 
behalf of the whole society, and they must be able to conduct investigations not only against citizens but sometimes against public authorities and members of governments regarding various offences such as corruption, embezzlement, abuse of power and other serious crimes. ${ }^{50}$ Also, the implied admittance (more accurately not objecting to the appointment of a female arbitrator) by the Administrative Court of Appeal to the appointment of a female arbitrator constitutes a step forward for women's participation in the judiciary because both arbitrators and judges perform a judicial function, ${ }^{51}$ but arbitration is usually a quicker way of arriving at a final and binding solution for a dispute. ${ }^{52}$ Accordingly, within a specific period of time, the arbitrator must deliver a ruling to the parties after fulfilling the many components that are usually involved as a typical courtroom trial. As such, during the arbitration process, arguments are made, evidence is presented, hearing heeded, and witnesses called and questioned by the parties. ${ }^{53}$ Indeed, appointing a woman as an arbitrator is a recognition of her capabilities since working as an arbitrator requires a high level of competence and accountability in facing the above-mentioned challenges within a specific timeframe.

\subsection{The Religious Constraints}

Most of the interviewees claimed that women cannot work in the judiciary because Sharíah only allows men to do this type of work. When asked to explain further, the interviewees failed to provide more details, relying only on the position of religion towards women in general. One judge said, 'Women are-from Islamic point of view-inadequate for the judiciary because they do not have the stamina. When asked as to the source of his religious information, he replied that he based his opinion on a Qur'ānic verse that says, 'Men are superior to women'.

It is noteworthy that, while the majority of the judges believed that women could not serve as judges on the bench, few of them stated that they understand that a woman's participation in the judiciary is still controversial. These

50 European Network of Councils for the Judiciary (ENCJ), 'Independence and Accountability of the Prosecution, ENCJ Reports 2014-2016', available online at https://www.encj.eu/ images/stories/pdf/workinggroups/independence/encj_report_independence_account ability_prosecution_2014_2016.pdf (accessed 12 June 2020).

51 M.M. el-Awa, 'Confidentiality in Arbitration: The Case of Egypt' (Cairo: Springer, 2016), p. 103 .

$5^{2}$ N. Mangard, Arbitration and the Judiciary, available online at https://svjt.se/svjt/1980/103 (accessed 12 June 2020).

53 FindLaw, What is Arbitration?, available online at https://www.findlaw.com/adr/arbitra tion/what-is-arbitration.html (accessed 12 June 2020). 
few judges agreed on the ability of women to work in the judiciary if they fulfilled all the required stipulations because they think that nothing in Sharīah refers expressly to prohibiting women from working in the judiciary. One of the judges reported, 'In my opinion, a woman can assume the judgeship if she meets all stipulations of appointment and that she can judge in family status cases because women are adequate and knowledgeable for this kind of cases only but not civil and criminal cases'. Another judge indicated that Sharīah does not object to qualified women participating in some important public functions such as a judgeship. He referred to examples of women who worked with rulings ( fatwo $\bar{a})$ and judiciary in Islamic history. He wondered, 'Isn't it the same Sharīah that permitted 50 women last year to join the public prosecution that is considered a judicial body?. When asked if he thought that the role of a female judge should be restricted to personal status issues, he explained that a woman could judge in all cases, including criminal cases, since women have already been admitted to work in public prosecution which deals with criminal cases within the criminal sphere.

This study shows, from the participants' perspective, that there are three directions regarding women's appointment in the judiciary: those who prohibit the appointment of women in the judiciary; those who permit women's appointments but under the condition that they only work in personal status cases, and those who agree with women working in the judiciary unconditionally. This corresponds with both Engy Abdelkader ${ }^{54}$ and Amira Bahay al-Din ${ }^{55}$ who concluded that, with restrictive interpretation of Shari`ah, women have been excluded from the judiciary and vice versa. In his limited interpretation of Islamic religious texts, $\mathrm{Abd}$ al-Hamid Mayhoub ${ }^{56}$ mentioned that in Islam a judge must be a man.

To make a rigorous case for women working as judges from a Sharīah point of view, it is relevant to examine the appointment of women in the judiciary from a practical Islamic perspective. There is neither an explicit text in the Qur'ān nor Sunnah that prohibits women from working as judges, ${ }^{57}$ and this opens the door for interpretation by Islamic scholars. The following section discusses the prohibition and permissibility of women as judges by Muslim jurists (scholars) based on their interpretations of Qur'ānic verses and the Sunnah. Thus, this part is divided into three sentiments.

54 Abdelkader, supra note 23.

55 Bahay el-Din, supra note 21.

56 Mayhoub, supra note 28.

57 A. Muneeza, Appointment of Female Judges in Muslim Countries (2014), available online at https://heinonline.org/HOL/LandingPage?handle=hein.journals/ejlr16\&div=21\&id=\& page $=($ accessed 12 June 2020 $)$. 
Most Muslim jurists ( $\check{g} u m h \bar{u} r$ ) argue that women are prohibited from working as judges. Therefore, if a woman is appointed as a judge, the one who appoints her will be sinning and the ruling she makes will be weightless because the appointment is not in conformity with Sharī'ah and, therefore, void. ${ }^{58}$ The Muslim jurists who adopted this perspective are Imām Mālik, Aḥmād ibn Hanbal, Al-Safi'î, and several jurists from the Hanafì school. ${ }^{59}$ They based their viewpoints on strict interpretation of Qurānic verses and Hadìth (what Muslims believe to be a record of the words, actions, and the silent approval of the Islamic Prophet Muhammad). ${ }^{60}$

\subsubsection{Verses from the Qur'ān}

Those founding jurists regarded women disqualified as judges because Qurānic Sürat an-Nisä' 4:34 (The Women) states that, 'Men are responsible (qawāmūn) for women by [right of] what Allah has given one over the other and what they spend [for maintenance] from their wealth [...]', which they interpret as men having guardianship over women, not the opposite. ${ }^{61}$ In other words, men assume guardianship and are not guarded over. This leads to the notion that it is prohibited for women to assume the position of judge as this would give women guardianship over men, and thus in conflict with what the Qurānic verse conveys. ${ }^{62}$

\subsubsection{Verses from Hadith}

Opponents of the appointment of female judges also based their view on the Prophet Muhammad's (pbuh) saying, 'Those who appoint a woman over them will not succeed. ${ }^{63}$ According to them, this is evidence that women should not hold sovereign, as avoidance of matters that induce failure is a duty, and this

$5^{8}$ S. Muhammad Saalih al-Munajjid, Islam Question \& Answers: 'Ruling on appointing a Woman as a Judge, available online at https://islamqa.info/en/answers/71338/ruling-on -appointing-a-woman-as-a-judge (accessed 12 June 2020).

59 N.N.N. Badlishah and Y. Masidi, Women as Judges, Kuala Lumpur Sisters in Islam, available online at https://catalogue.nla.gov.au/Record/4726423 (accessed 12 June 2020).

6o Ibid.; See also: J.A.C. Brown, Misquoting Muhammad, the Challenge and Choices of Interpreting the Prophet's Legacy, available online at https://archive.org/stream/misquo ting-muhammad-pbuh/misquoting-muhammad-pbuh_djvu.txt (accessed 13 June 2020).

61 Badlishah and Masidi, supra note 59.

62 M. Rafat Osman, Al-Nizam al-Qadāi fì l-Fighi l-Islamī (Cairo: Maktabat al-Falah, 1989), p. 88.

63 M. bin Ismael al-Bukhari, Al-Jāmíah al-Saḥ̄ḥ (Beirut: Dār Ibn Kathīr, 1987), p. 1610. 
is what the Hadith explicitly indicated. ${ }^{64}$ They argue that the Prophet in the Hadìth uses general, not specific, terms, such as 'People who entrust a woman with a khiläfah, an emirate, or a judgeship, or any other public authority, will not succeed'; thus, the Hadith cannot be interpreted as intending the khiläfah only. ${ }^{65}$ To them, use of the Hadith of the general term implies that all public authorities of the state are included since legists conferred that general ruling, in any case, applies to all individuals of that generalization. ${ }^{66}$

Jurists denying the right of women to be judges argue that the Prophet (pbuh) confirmed the shortcoming in women's intellect and religion, with the due explanation of the cause of the rule. ${ }^{67}$ The Prophet Muhammad says:

What I have seen of shortcoming in intellect and religion of women affirms the rationality of the sensible man among you. 'The woman said, "what is that, Messenger of God?". The Prophet (pbuh) said, 'Don't you spend nights without praying or fasting?', that is an example of their shortcoming in religion, 'is not the witness of one of you is worth half that of man's witness? This is due to their shortcoming of women's intellect'.68

This implies a natural disposition with which Allah has created woman. The conclusion of this guidance is that women are unfit to assume judgeship. ${ }^{69}$

Furthermore, they said that women do not have custody over themselves in marriage, so how could they have custody over others in the judiciary since, as a judge, a woman may order marriages or divorces? ${ }^{70}$ To them, women's nature is governed by emotions, and thus they are incapable of deciding lawsuits that require objectivity and decisiveness. ${ }^{71}$

In this context, in $195^{2}$ the Fatwa Committee of Al-Azhar issued a fatwa a that nullified the appointment of women judgeship as, 'There is general consensus that women are not suitable for judicial authority and it is sinful to charge her

64 A. bin Mohamed al-Mawardi al-Baghdadi, Al-Aḥkām al-Sultaniyyah (Cairo: Al-Babi al-Halabi, 1975), p. 65.

65 Mayhoub, supra note 28 at 43-44.

66 Al-Baghdadi, supra note 64; Mayhoub, supra note 28.

67 A.A.A.A. Daghi, Mas'el Shar'ya fee Kadaya Almar'aa (Malaysia: International Islamic University Malaysia Press, 2011), p. 26.

68 Daghi, ibid., p. 35 .

69 Mayhoub, supra note 28 at 44 .

$70 \quad$ Daghi, supra note 67 at 28.

71 H. Muhammad Hassan, 'Women Assuming Judgeships in Islamic Jurisprudence and Egyptian and International Law', in A. Moneim Muslim (ed.), Women Judges in the Arab Region: Point, Counterpoint (Cairo: The Arab Center for Independence of the Judiciary and the Legal Profession 'ACIJLP', 2001), p. 12. 
with such. The matter is not open for interpretation unless binding proof is had, for there is consensus on the matter. ${ }^{72}$

The inability of women to hold the position of judge finds its justification, in view of this group of jurists, in practice that neither the Prophet (pbuh) nor any of the khaliffats nor their successors have entrusted women with the administration of justice or the governance of a country. ${ }^{73}$ This indicates that women are unfit for the governance of countries (al-imāmat al-kubrā) and judiciary authority. Thus, being indisputably male is a stipulation. ${ }^{74}$

\subsubsection{The Second Sentiment: Arguments for a Moderate Position between Prohibition and Permissibility}

Hanafi jurists took an intermediate position between that of the majority of jurists and Ibn Jarīr al-Ṭabarī and Ibn Ḥazm; they neither completely denied women's authority in the judiciary nor completely condone it; rather they assumed that women could be judges in cases of finances, ${ }^{75}$ where they are permitted to witness. ${ }^{76}$ Imām Abū Hanifah reached this view based on his interpretation of Qurānic verse 2:282, Sūrat al-Baqarah (The Cow):

O you who have believed, when you contract a debt for a specified term, write it down. And bring to witness two witnesses from among your men. And if there are not two men [available], then a man and two women from those whom you accept as witnesses-so that if one of the women errs, then the other can remind her. ${ }^{77}$

Abū Ḥanifah said, 'Being a male is not a condition for assuming judgeship, as women hold the credentials to judge; however, women may not judge in legal punishment because they have no credentials to do so.'78

72 Md.Y. Ali, The Appointment of Muslim Women as Judges in the Courts: A Textual Analysis from Islamic Perspective, available online at http://www.ipedr.com/voliz/37-CHHSS\%2O 2011-H1oo39.pdf (accessed 2o June 2020).

73 Osman, supra note 62 at 10o; Daghi, supra note 67 at 44.

74 Ibid.; Mayhoub, supra note 28 at 47.

75 Daghi, supra note 67 at 18.

76 E. Fawzi, 'Women Occupying Judiciary Position in Egypt: A sociological Reading of Responses from a Limited Sample of Cairenes', in Abdel Moneim Muslim (ed.), Women Judges in the Arab Region: Point, Counterpoint (Cairo: The Arab Center for Independence of the Judiciary and the Legal Profession 'ACIJLP', 2001), p. 22.

77 Qurān 2:282.

78 Mayhoub, supra note 28 at 43 . 
Other Islamic jurists argue that there is neither a text in the Qur'ān or Sunnah that expressly prohibits women from working as judges. ${ }^{79}$ Ibn Hazm, Ibn Jarīr al-Ṭabarī, Hasan al-Bașrī and Ibn al-Qāsim (belongs to the Mālikī school) claim that women may hold positions as judges in all cases without exception as long as they fulfill the requirements for the position. ${ }^{80}$ Such requirements include adultness, sanity, trustworthiness, and knowledge of Sharī'ah. ${ }^{81}$

Those jurists drew their conclusion from the holy verse: 'God commands you to deliver trusts back to their owners; and when you judge between the people, that you judge with justice'. ${ }^{82}$ In their view, this text is general discourse, so it is directed at men, women, slaves, and freemen. ${ }^{83}$ This can be derived from the Qurānic Sūrat al-Tawbah: 'The believing men and believing women are allies of one another. They enjoin what is right and forbid what is wrong and establish prayer and give $z a k a \bar{h}{ }^{84}$ and obey Allah and His Messenger. Those-Allah will have mercy upon them. Indeed, Allah is Exalted in Might and Wise'.85 Clearly, this Sürah could be applied to all people, men and women rather than just men.

During the era of Prophet Muhammad (pbuh), women participated in fatwa and were members of the advisory council entrusted with the task of giving advice to people. ${ }^{86}$ In addition, according to Ibn Hishām, when Prophet Muhammad (pbuh) held the first parliament at Aṣ-Șafā, both men and women were included in that meeting. During the Abbasid Caliphate (khiläfat), a 'woman member', Fā'iqah bint 'Abdullah, sat on the royal court council and resolved disputes between people. ${ }^{87}$ Ibn Jarīr said, 'Being a male is not a condition and yet women are freely permitted to assume the judiciary'. Ibn Jarīr based allowance for women to hold the position of judge on analogy. He said, 'Women may be al-muftin and thus be judges, based on the analogy of rendering judgment to that of rendering Islamic judgment $(\text { fatwa })^{\prime} \cdot{ }^{88}$ Ibn Hazm replied

\footnotetext{
79 Daghi, supra note 67 at 5 o.

8o Daghi, ibid., p. 21.

$81 \quad$ Ibid.

82 Qửān 4:58.

83 Daghi, supra note 67 at 46 .

84 Ibid.; zakāh is a mandatory charitable contribution, often considered to be a tax. R.W. Hefner, 'Islamic economics and global capitalism', Society 44(1) (2006): 16-22.

85 Qurān 9:71.

86 G. Murad, 'Women and the Judiciary in the Arab World: Present and Future', in N. Amin (ed.), The State of the Judiciary in the Arab Region (Cairo:The Arab Center for Independence of the Judiciary and the Legal Profession (ACIJLP), 2001), p. 8o.

87 Ibid.

88 Albaghdadi, supra note 64 at 65; Mayhoub, supra note 28 at 43.
} 
to those who argued that women were not qualified to be khiläfah hence not to be judges, explaining that the Prophet's saying is confined to khalifah only, which indicates the correctness of the Prophet's saying that women are the guardians of their husband's money and are responsible for their children. ${ }^{89}$

This group of jurists also argued that 'Umar Ibn al-Khațāab, the second Rightly Guided Caliph (khalïfah), appointed a woman named Al-Shifä' al-Adawiyyah to monitor the city market; ${ }^{90}$ a woman named Sāmrā bint Nahilk al-Asadiya also held this position. They patrolled the market ordering, forbidding, and beating people with a whip. ${ }^{91}$ Women administered the market; thus they may work as judges as each of these jobs has the element of public power. ${ }^{92}$ Interestingly, it can be understood from the above-mentioned information that the patrolling women were not only administering the market, ordering / forbidding people, but they were also executers of punishment (beating with a whip).

It is argued that women not assuming the profession of judges during the era of Prophet Muhammad or his four successive khaliffah during early Islamic history is not grounds for preventing them from assuming such a task in the absence of an explicit Qurānic text and Sunnah that prohibits the appointment of women in the judiciary or restricts the function of deciding disputes to men only. ${ }^{93}$ It can be said that women did not work as judges during the above-mentioned era because not many judges were needed to rule, due to the safety and security prevailing at that time. ${ }^{94}$

A number of reputable contemporary Islamic jurists believe that women are able to hold any position for which they are qualified with the exception of the khilāfat, including Muhammad al-Ghazālī, ${ }^{95}$ Muhammad Sa 'īd al-Būțī, Yūsif al-Qaraḍāwī, 'Abdel Karīm Zīdān, Samir Aia, 'Abd al-Ḥalīm Abū Shaqqah. Egypt's former grand muftī, Sheikh 'Alī Jum'ah, stated that the appointment of women to judicial positions does not contradict Islamic precepts. 'The job of a judge is merely to know the law well and to implement it fairly. The inclusion of women is a right owed to society as a whole. ${ }^{96}$

\footnotetext{
89 Daghi, supra note 67 at 24.

9o S. Khan, 'Facts about Islam' (2014), avaialble online at: https://www.whyislam.org/muslim -heritage/al-shifa-bint-abdullah/ (accessed 15 January 2021).

$91 \quad$ Fawzi, supra note 76 at 22.

92 Mayhoub, supra note 28 at 48.

93 Daghi, supra note 67 at 44.

94 E. Nurlaelawati and A. Salim, 'Gendering the Islamic Judiciary: Female Judges in the Religious Courts of Indonesia', Al-Jāmi'ah 51(2) (2013): 247-278.

95 Daghi, supra note 67 at 21.

96 Horizon Institute, Women and the Judiciary in Somali Land, available online at https:// www.thehorizoninstitute.org/usr/library/documents/main/women-and-the-judiciary -paper.pdf (accessed 1 July 2020).
} 
The above discussions show that the appointment of women in the judiciary is a debatable issue by Islamic jurists. Jurists' points of view varied. Some jurists adopted an absolute prohibition of appointment in the judiciary; some adopted a woman's appointment but with conditions; and some agreed on a woman's appointment without any conditions, which corresponds with what the judges mentioned in the interviews. Such variation in viewpoints can be looked at optimistically since there is no absolute rejection by all the jurists so there is little light at the end of the tunnel. In other words, since there is more than one interpretation to the different texts, why not rely on the most flexible interpretation and allow women to work in the judiciary, especially that constitutional and legal authorization already exist. Although Al-Azhar is the most conservative Islamic institution in the world, it relied on the permissible interpretation to enroll women in the judiciary.

Appointing competent women in the judiciary in Saudi Arabia has become a legal necessity and 'necessities remove restrictions. This need is enhanced with the increase of the populations' numbers, the increase of disputes and judicial cases before courts accordingly, and the increase of female law graduates' ${ }^{97}$

\subsubsection{The Cultural Constraints}

There was near consensus among the interviewed judges that the prevailing issue of gender stereotypes and norms constitutes a cultural barrier for women from working in judiciary. They affirmed that the cultural beliefs of their Saudi society were based on different interpretations of provisions of Shari`ah.

One judge who stated that Sharīah does not allow women to work in the judgeship explained, 'It is difficult for them and for the members of the society in general and for the litigants in particular to accept females as judges. They prefer seeing women as good wives and great mothers whose task is way more important than the task of their role as judges'. Another judge stated that 'people of society may tolerate women's participation in any field but not in the judiciary'. Three judges think - from their experience - that disputants trust male judges and they may lack the confidence in the ability of female judges due to the emotional and biological status of women and due to their beliefs that men are superior to women. Four participants emphasized the fact that Saudi society is changing and women should be appointed as judges.

Claims made with regard to the inability of women to work as judges due to their vulnerability and weakness can be disputed; women being emotional and Less Oppressive for Muslim, available online at https://sunnahonline.com/library/ fiqh-and-sunnah/105-necessity-removes-restriction (accessed 1 July 2020). 
by nature does not constitute a barrier because male judges can be emotional as well. In addition, the process of judging does not require oppressing emotions and disregarding the human considerations. ${ }^{98}$ Thus, women having emotions cannot be considered a flaw against them if such emotions are just to enhance the sense of fairness and increase the perception of impartiality and justice but not to exert influence on decisions. Undoubtedly, in the war between judicial heart and judicial head, the judicial head is supposed to prevail always regardless of the judge's gender. ${ }^{\prime 9}$ As such, judges do not rule by emotions, but they are restricted to the rule of law in the conflicts represented before them. ${ }^{100}$

Opponents to women assuming the task of judge argue that the biological changes such as menstruation, childbirth, and pregnancy make women incapable of working as judges as it would burden them physically and burden the work environment with having the symptoms of the biological changes like nervousness, instability, and inflexibility during discussing lawsuits with colleagues and vulnerability to sudden changes. ${ }^{101}$ Also, the conception of women's deficiencies was expressed by one Islamic leader, Sheikh 'Alī Jum'ah, who showed support for appointing women as judges in Egypt. He stated, 'Everyone knows the weak psychological state of women during menstruation. What would she do if the disturbances of pregnancy in its final months darkens her mood and wears out her nerves and thus, she becomes ill-tempered and unfit for the serious trusteeship of the judiciary?102

Some opponents argue that women's tone of voice, attractiveness, and appearance would invite temptation ${ }^{103}$ to some men, which might lead to adultery and unethical behaviours. ${ }^{104}$ In response, if such an opinion is taken seriously into consideration, it means that women will not be able to do any kind of work rather than that of a mother or a wife where she will be kept inside her house whereas we see women occupying jobs with male co-workers in different private and public sectors. Moreover, courts are workplaces for all litigants including women. Mixing is already happening between the two sexes. In addition, women who would be appointed in the judiciary are supposed to be competent and of high values and ethics; therefore, they know

\footnotetext{
$98 \quad$ Hassan, supra note 71 at 13 .

99 A.J. Wistrich, J.J. Rachlinski and C. Guthrie, 'Heart Versus Head: Do Judges Follow the Law or Follow Their Feelings?', Texas Law Review 93(855) (2015): 911.

100 Wistrich, Rachlinski and Guthrie, ibid., p. 909.

101 Hassan, supra note 71 at 13.

102 Fawzi, supra note 76 at 29.

103 Mayhoub, supra note 28 at 48.

104 Ali, supra note 72 at 203.
} 
how to control their tone of voice, safeguard their bodies from any unethical behaviour, and restrain the eyes from 'evil desires' in public; they can maintain their task of motherhood and fulfil the rights of a husband in order to have a happy marital life without jeopardizing their careers. ${ }^{105}$

The purpose of this study was to identify and discuss the factors that prevent women from working as judges in Saudi Arabia from the perspective of male Saudi judges. The barriers identified were divided into three main themes: legal, religious and cultural barriers.

There is no legal constraint that prevents women from becoming judges because no gender stipulation was found in any of the laws that the study referenced. In terms of religious barriers, Islamic jurists adhere to different opinions, and the most classical (conservative) Islamic schools prohibit women from serving as judges. However, some Islamic jurists believed in women becoming judges. The cultural barrier is most closely linked to religion, and there is a mainstream aversion against women's employment in the judiciary.

This research concludes that no restraints prevent women from becoming judges despite the fact that all the participants revealed-from their perspectives as judges - possible barriers for preventing women from working in the judiciary. Given the fact that the Law of the Judiciary in Saudi Arabia does not stipulate maleness as a condition for appointing people in the judiciary, submitting a proposal by members to the Shüra Council in order to vote on women's employment in the judiciary seems irrelevant because the task of the Shüra Council as a legislative body is to enact laws or to reform an existing law rather than propose or make a decision for women to work in the judiciary. When 50 women were accepted to join the public prosecution in 2018, the Shüra Council had nothing to do with their appointment. The same applies to appointing the first female arbitrator. Notably, neither the Public Prosecution Law nor the Arbitration Law has a gender stipulation regarding such an appointment; therefore, women were appointed in these two legal professions. Using the same analogy, appointing women in the judiciary could be a matter of time because of the similarity of the three laws.

Ultimately, since the legal system does not prohibit women's appointment in the judiciary, it seems that the main obstacle can be found in the different interpretations by Islamic jurists on women's appointment in the judiciary,

105 Ali, ibid. 
and the influence such interpretation leaves on people regarding acceptance or refusal. Therefore, it is relevant to rely on the interpretation that allows women to work as judges such as when Al-Azhar implemented the permissible Islamic interpretation in order to allow women to work as judges as mentioned earlier in this study.

Importantly, social and educational awareness should be campaigned in education such as schools and universities on the empowerment of women in general and on their involvement in the judiciary in particular. The media can also play an important role in raising the visibility of women within the judiciary as positive partners in administering the justice. To explain, some restrictions on women have been eased in many activities such as driving and travelling without a male guardian's approval.

Further, according to Article $5^{2}$ of the Law of the Judiciary, the Supreme Judiciary Council is tasked with selecting people for appointment in the judiciary. If it is important to raise social and educational awareness among members of the society to look at the religious texts comprehensively, it is equally important for members of the Supreme Judiciary Council to adhere to objectivity during the process of selecting judges regardless of their gender.

In conclusion, this research examined the points of view of male judges and discussed the factors they mentioned from religious, legal, and cultural aspects; a subject for future research could be acceptance of the idea of the appointment of women judges from women's viewpoints including female law graduates and female lawyers. 